\title{
EFFECT OF POTASSIUM SILICATE AND CHELATED CALCIUM SPRAYS ON YIELD, QUALITY AND STORAGE OF PEACH FRUITS CV. "DESSERT RED"
}

\author{
M.H. Abd El-Aziz, M. A. Soliman and H. A. Ennab \\ Horticulture Research Institute, Agriculture Research Center, Giza, Egypt \\ Received: Mar. 4, 2021 \\ Accepted: Mar. 15, 2021
}

\begin{abstract}
ABESTRUCT: The present work was conducted on ten years old "Dessert Red" peach (Prunus persica L.) trees grown in a private orchard at El-Riad, Kafr El-Sheikh governorate, Egypt. This study carried out during 2019 and 2020 seasons to evaluate the effect of pre-harvest foliar applications of potassium silicate at $0.1,0.2$, and $0.3 \%$, calcium EDTA at 0.1 and $0.2 \%$ in addition to control treatment on yield, fruit quality and storability of peach fruits at $0 \pm 1^{\circ} \mathrm{C}$ with $90-95 \% \mathrm{RH}$. Results showed that all preharvest foliar application treatments led to increase yield (fruits weight as $\mathrm{kg} /$ tree and ton/feddan) and improved fruit quality compared with control treatment. Foliar spraying with $\mathbf{T}_{7}$ $\left(\mathrm{K}_{2} \mathrm{SiO}_{3}\right.$ at $0.3 \%$ + Calcium EDTA at $\left.0.2 \%\right)$ and $\mathrm{T}_{6}\left(\mathrm{~K}_{2} \mathrm{SiO}_{3}\right.$ at $0.2 \%$ + Calcium EDTA at $\left.0.2 \%\right)$ showed the highest yield and more effective in improving fruit quality in terms of fruit weight, length, diameter, volume, firmness, SSC\% and vitamin C content at harvest time as compared to control in both seasons. Moreover, these applications showed the highest values of vitamin C content, juice acidity \% and the lowest values of weight loss $\%$ up to 28 days of cold storage in both seasons. While, application of $\mathrm{K}_{2} \mathrm{SiO}_{3}$ at $0.3 \%+$ Calcium EDTA at $0.2 \%$ recorded the highest fruit firmness values and the lowest fruit decay \%, and maintained fruit SSC\% and anthocyanin content during all storage periods in both seasons. Therefore, it can be recommend to spray this treatment $\left(\mathrm{K}_{2} \mathrm{SiO}_{3}\right.$ at $0.3 \%$ + Calcium EDTA at $0.2 \%$ ) three times to increase yield, improve quality, and maintain peach fruit quality during cold storage.
\end{abstract}

Key words: Peach, pre-harvest, potassium silicon, calcium

\section{INTRODUCTION}

Peachs (Prunus persica L.) is one of the most important deciduous fruit that grows successfully in the newly reclaimed areas in Egypt. The fruits are consume freshly and caned as lick jam or jelly (El-Badawy, 2012). Peach fruits show a climacteric behavior and deteriorate quickly after harvesting. Peach fruits show a rapid increase in the ethylene production with rapid ripening which limits the shelf life of fruits (Brummell et al., 2004 and Valero et al., 1997). This short post-harvest life may be related to fruits quickly pass from normal maturity to the over-ripening phase. Moreover, peaches are extremely perishable fruits, so it has a short storage life (Crisosto et al., 1997 and Lurie and Crisosto, 2005). Therefore, there is a need to ascertain pre and post-harvest applications for maintaining fruit quality for long periods. Nutritional status of trees is one of the most important factors that for increasing yield and improve quality and extend the postharvest life of fruits (Toliba et al., 2014b and Schirra et al., 1999). Calcium is an element used for achieving this purpose since, the deficiency of which may lead to a range of postharvest disorders of fruits (Shear, 1975). Calcium plays an important role in stabilizing the cellular membranes and retarding fruit senescence in horticultural crops and helps to format the linkages between pectic substances (Poovaiah et al., 1988). In addition, Chardonnet et al. 
(2003) explained that Cell wall-bounded $\mathrm{Ca}$ is involved in maintaining cell wall integrity by binding carboxyl groups of polygalacturonate chains, which are mainly present in the middle lamella and primary cell wall. Several researchers cleared the important role of calcium in enhancing and maintaining fruit quality (Barker and Pilbeam, 2015 and Zambrano-Zaragoza et al., 2014). In this line, Serrano et al., (2004) concluded that, pre-harvest calcium applications enhanced calcium levels of the cell wall which delayed fruit senescence, maintained firmness, and showed a higher fruit quality of peach in. In this respect, Ali et al. (2014) reported that calcium application significantly raising the level of calcium in both leaves and fruits of peach cv. 'Florida King' so it considered a safe chemical, which improve peach fruit quality. In addition, Mazahir et al. (2018) reported that the application of $\mathrm{Ca}^{++}$before harvesting time of fruits might be the safest and most effective method for improving the fresh fruit quality and extending fruit shelf life.

Silicon is one of the superabundant elements since it reached about $29 \%$ of the Earth's crust (Guntzer et al., 2012). It is considered a quasi-essential element because of the benefits that offered to plants as lick enhancing growth, yield fruit quality, and mitigate biotic and abiotic stresses (Van-Bockhaven et al., 2013). The beneficial effects of Si were suggested through enhancing photosynthetic activity, improving $\mathrm{K} / \mathrm{Na}$ ratio, stimulate the activity of some enzymes activity, increasing the soluble substances of the plant xylem, and encourage antioxidant defense mechanism of plants (Meena et al. (2014). Moreover, potassium silicate is a source of soluble potassium and silica, so it could be used as amendment in agricultural production, since it benefits enhancing tree yields, fruit volume, fruit color, shelf life, and improving the quality
(Kanai et al., 2007). In this respect, Zhang and Ervin (2008) reported that, silicon applications retarded fruit softening through suppression effect on some enzymes as xylanase, cellulase, and polygalacturonase activity. In this line, Al-Wasfy (2014) concluded that, silicon applications in" Flame seedless" grape enhanced vine growth, improved yield, and quality. The potential effects of silicon during cold storage were cleared by Mditshwa (2012) who concluded that application of $\mathrm{K}_{2} \mathrm{SiO}_{3}$ to Eureka' lemon fruits that stored at a different cold temperature $\left(-0.5,2\right.$, and $\left.4.5{ }^{\circ} \mathrm{C}\right)$ under $90 \%$ RH for 28 days +5 days at $20^{\circ} \mathrm{C}$ significantly reduced chilling injury symptoms as to compared to control. Si applications increased both phenolic and flavonoid antioxidants of fruit during cold storage so that, maintained cell membrane integrity (Mditshwa et al., 2013). In addition, Nasar et al. (2013) showed that Pioneer plums treated by 500 and $2500 \mathrm{ppm}$ potassium silicate and storage at $0 \pm 1^{\circ} \mathrm{C}$ for 28 cleared less cell permeability which estimated as electrolyte leakage.

The aim of this work is to evaluate the potential effects of pre-harvest foliar application of potassium silicate and calcium EDTA on yield, fruit quality, and storability of 'Dessert Red' peach fruits.

\section{MATERIALS AND METHODS}

This study conducted during the 2019 and 2020 seasons on ten years old peach cv. 'Dessert red' (Prunu spersica L.) trees in a private orchard at El-Riad, Kafr ElSheikh governorate, Egypt. The trees grafted on Nemagard rootstock and spaced at $4 \times 4 \mathrm{~m}$ in clay soil under flood irrigation system. The soil texture was clay $(61.35 \%$ clay, $31.50 \%$ silt, and $7.15 \%$ sand at 0 to $90 \mathrm{~cm}$ of soil depth) with $1.22 \%$ organic matter, $1.83 \mathrm{dSm}^{-1}$, a $\mathrm{pH}$ of 7.82 and water table at $1.7 \mathrm{~m}$. Forty-two trees were selected as uniform as 
possible in growth, vigor, fruiting, and free from any visual disease. The trees received the recommended orchard management. The trees were arranged in randomized complete blocks design and subjected to seven foliar applications (Control, potassium silicate at $0.1,0.2$ and $0.3 \%$; and $\mathrm{Ca}^{++}$EDTA at 0.1 and $0.2 \%$ and interaction among them) each treatment replicated three times with two trees per replicate. The treatments arranged as follow:

$\mathrm{T}_{1}$-Control (tap water)

$\mathrm{T}_{2}$ - Potassium silicate at $0.1 \%+\mathrm{Ca}^{++}$EDTA at $0.1 \%$

$\mathrm{T}_{3}$ - Potassium silicate at $0.2 \%+\mathrm{Ca}^{++} \mathrm{EDTA}$ at $0.1 \%$

$\mathrm{T}_{4}$ - Potassium silicate at $0.3 \%+\mathrm{Ca}^{++}$EDTA at $0.1 \%$

$\mathrm{T}_{5}$ - Potassium silicate at $0.1 \%+\mathrm{Ca}^{++}$EDTA at $0.2 \%$

$\mathrm{T}_{6}$ - Potassium silicate at $0.2 \%+\mathrm{Ca}^{++}$EDTA at $0.2 \%$

$\mathrm{T}_{7}$ - Potassium silicate at $0.3 \%+\mathrm{Ca}^{++}$EDTA at $0.2 \%$

The treatments were applied three times: the first one was done after fruit set 20 and 23 March and then, the second and third one at 15 day intervals in both seasons, respectively. The applications were done by using a hand sprayer with solution $5 \mathrm{~L}$ per tree in the morning.

The following data were recorded:

\section{Total yield}

At harvest period (16 and 19 May in both seasons, respectively) when peach fruits reached SSC $11 \%$ and firmness about $4 \mathrm{lb} / \mathrm{inch}^{2}$ as recommended by Carlos (1994), the yield per each tree was determined (kg/tree) and the total yield was calculated (ton/feddan).

\section{Fruit physical parameters}

During harvest time, fruit samples (5Kg fruits per treatment) picked and then directly translocate to the laboratory of Sakha Horticulture Research Station, Kafr El-Sheikh governorate within two hours. Fruits cleaned and washed with distilled water and then left until the surface of the fruits were dried. Samples of fruits (12 fruits per treatment) were used to determine fruit physical measurements such as weight of fruit (g) using digital balance, fruit volume $(\mathrm{ml})$ by using water displacement method, fruit length $(\mathrm{cm})$, and diameter $(\mathrm{cm})$ with the help of digital caliper. Fruit firmness was determinate $\left(\mathrm{g} / \mathrm{cm}^{2}\right)$ by Effigi pressure tester (mod. Ft327). Fruit firmness data were converted into Newton unit by using the standard factor (1 gram-force = 0.00980665 Newton) according to (A.O.A.C., 1990).

\section{Storability studies}

The remained fruit sample of each treatment $(4 \mathrm{~kg})$ was divided into four groups each one packed in carton boxes as one layer; each box contained $1 \mathrm{~kg}$ of peach fruits. Carton boxes were translocate to cold storage at $0 \pm 1^{\circ} \mathrm{C}$ with $90-95 \%$ RH. At 7 day intervals for 28 days of cold storage, the following parameters recorded:

Weight loss (\%) was calculated according to the initial weight of fruit (before storage) and fruit weight after each storage period using the following equation: weight loss $\%=100^{*}\left(W_{0}-W_{p}\right)$ / $\mathrm{W}_{0}$, Where, $\mathrm{W}_{0}=$ fruit weight before storage. $W_{p}=$ fruit weight after each storage period.

Fruit decay (\%) was determined as the number of decayed fruits per fruit number of each ex-storage sample date and expressed as a percentage of fruit decay by using the following equation: Fruit decay $\%=100^{*}$ (fruits decay NO. Initial stored fruits NO. ).

Fruit firmness estimated as showed previously (N).

SSC \%, acidity \% and SSC/acid ratio: soluble solids content was determined with the help of handily refractometer, juice titratable acidity was determined using titration method and expressed as a percentage of malic acid/100 ml of juice (A.O.A.C., 1990), and SSC/acid ratio was calculated. 
M.H. Abd El-Aziz, et al.,

Ascorbic acid and anthocyanin pigments: Ascorbic acid was determined as $\mathrm{mg} / \mathbf{1 0 0}$ mljuice according to Jacobs (1951). In addition, anthocyanin pigments content was determined according to Rabino et al. (1977) and expressed as $\mathrm{mg} / \mathbf{1 0 0 \mathrm { g }}$ fresh weight. The previously chemical quality parameters also measured at the harvesting date.

\section{Statistical analysis}

The experiment was arranged as a randomized complete blocks design and the collected data were statistically analyzed according to Snedecor and Cochran (1990). Means of treatments were compared according to Duncan (1955) by using Duncan's multiple range tests (DMRT) at 0.05 levels.

\section{RESULTS AND DISCUSSION}

\section{Total yield}

Data illustrated in Figure 1 clear that, foliar application of potassium silicate plus chelated calcium significantly increased Peach fruit yield per tree as $\mathbf{k g}$ consequently as ton/feddan in both seasons. The highest yield was obtained from trees sprayed with potassium silicate at $0.3 \%$ plus chelated calcium at $0.2 \%$ followed by those sprayed with potassium silicate at $0.2 \%$ plus chelated calcium at $0.2 \%$ as compared with control and other treatments in both seasons. However, the lowest Peach fruit yield produced by trees of control in both seasons. The enhancement effect of treatments might be due to the important role of both potassium and calcium as macronutrients in tree growth and productivity (Mohamed et al., 2020). Moreover, Preciado-Rangel et al. (2018) summarized that potassium concentration in plant tissues and organs affects the accumulation of carbohydrates consequently yield and chemical fruit quality. These results are in harmony with those of Ali et al. (2014) they reported that application of $\mathrm{CaCl}_{2}$, putrescine, and salicylic acid increased fruit weight, fruit diameter, and yield of 'Florida King' peach cultivar as compared to control, the highest fruit yield was recorded with the spraying of $\mathrm{CaCl}_{2}$ at $1 \%$ and putrescine at $2 \mathrm{mM}$. These results in agreed with those of Nagy (2018) on apricot and Mosa et al. (2016) on "Florida prince" peach.

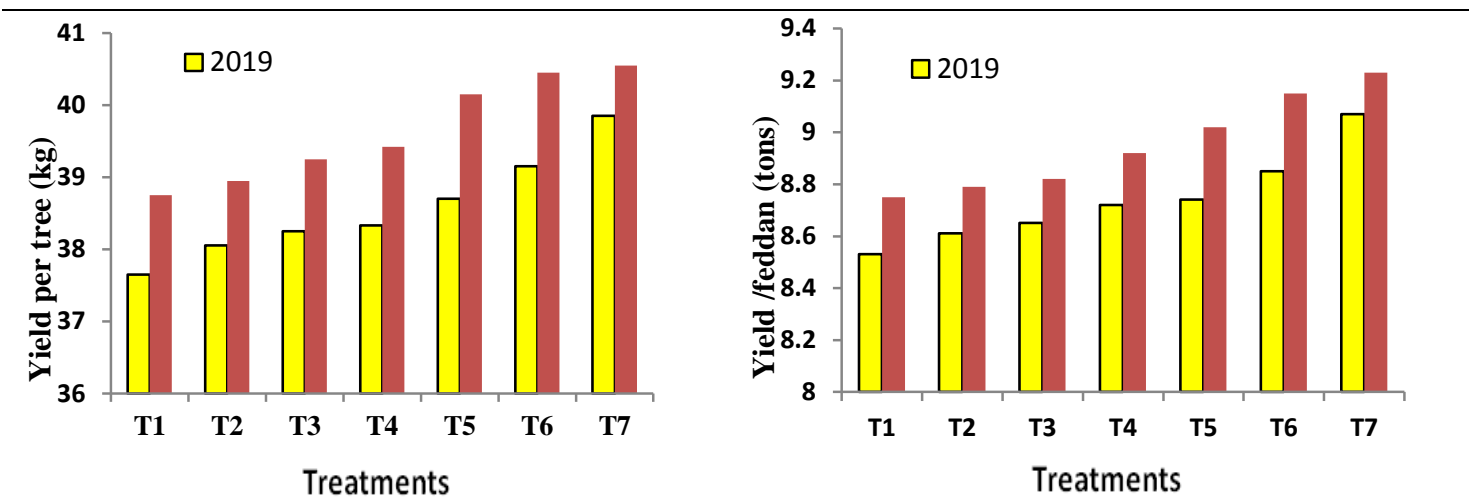

Figure1. Effect of potassium silicate and chelated calcium sprays on yield/tree and yield/ feddan of "Dessert Red" peach during 2019 and 2020 seasons

In a column, numbers flowed by the same litter are not significant at $5 \%$ by DMRT.

$\mathrm{T}_{1}$-Control (tap water), $\mathrm{T}_{2}$ - potassium silicate at $0.1 \%+\mathrm{Ca}$ EDTA at $0.1 \%, \mathrm{~T}_{3}$ - potassium silicate at $0.2 \%+\mathrm{Ca}$ EDTA at $0.1 \%, \mathrm{~T}_{4^{-}}$potassium silicate at $0.3 \%+\mathrm{Ca}$ EDTA at $0.1 \%, \mathrm{~T}_{5^{-}}$potassium silicate at $0.1 \%+$ Ca EDTA at $0.2 \%, \mathrm{~T}_{6}$ - potassium silicate at $0.2 \%+\mathrm{Ca}$ EDTA at $0.2 \%$ and $\mathrm{T}_{7^{-}}$potassium silicate at $0.3 \%+\mathrm{Ca}$ EDTA at $0.2 \%$. 


\section{Fruit physical characters}

Data in Table 1 clear that, all foliar applications of potassium silicate combined with chelated calcium had a positive significant effect on fruit characters as like fruit weight, length, diameter, and volume of "Dessert Red" peach compared to control in both seasons. Spraying Peach trees with the higher concentrations of both potassium silicate and chelated calcium was more effective to enhance yield and fruit quality characters. Peach trees that sprayed with $\mathrm{T}_{6}$ (potassium silicate at $0.2 \%+\mathrm{Ca}$ EDTA at $0.2 \%$ ), as well as $\mathrm{T}_{7}$ (potassium silicate at $0.3 \%$ + Ca EDTA at $0.2 \%)$ showed the highest fruit weight, length, diameter, and fruit volume followed in descending order by $T_{5}$ (potassium silicate at $0.1 \%$ + Ca EDTA at $0.2 \%$ ) in both seasons, respectively. On the contrast, the lowest values were recorded with control trees in both seasons. These results are in agreement with those of Ali et al. (2014) and Kuchay et al. (2018). In this respect, Shahid et al. (2020) reported that, the highest fruit weight of Florida King' peaches was obtained in trees that received a foliar application of $\mathrm{CaCl}_{2}$ at $3 \%$ while minimum values were in the case of control. In addition, El-Alakmy (2012) on Peach and Kirmani et al. (2013) on Plum showed an increase in fruit volume because of foliar application of calcium chloride. Moreover, it enhances ammonium uptake, which improves photosynthesis and $\mathrm{CO}_{2}$ intake that resulted in increasing fruit weight, volume, and yield (Shahid et al., 2020). Moreover, several searchers showed the positive effect of all sources of silicon in improving yield and fruit characteristics of different fruit crops (Kanai et al., 2007; El-Khawaga, 2014, and Abd El-Wahab, 2015).

Table 1. Effect of potassium silicate and chelated calcium sprays on some quality parameters of "Dessert Red" peach fruits during 2019 and 2020 seasons

\begin{tabular}{|c|c|c|c|c|c|c|c|c|}
\hline \multirow{2}{*}{ Treatments } & \multicolumn{2}{|c|}{ Fruit weight (g) } & \multicolumn{2}{|c|}{$\begin{array}{l}\text { Fruit length } \\
\text { (cm) }\end{array}$} & \multicolumn{2}{|c|}{$\begin{array}{l}\text { Fruit diameter } \\
\text { (cm) }\end{array}$} & \multicolumn{2}{|c|}{$\begin{array}{l}\text { Fruit volume } \\
\text { (ml) }\end{array}$} \\
\hline & 2019 & 2020 & 2019 & 2020 & 2019 & 2020 & 2019 & 2020 \\
\hline$T_{1}$ & $83.52^{c}$ & $90.24^{c}$ & $5.21^{c}$ & $5.43^{c}$ & $4.92^{c}$ & $5.26^{d}$ & $77.55^{f}$ & $83.27^{f}$ \\
\hline $\mathrm{T}_{2}$ & $87.19^{b c}$ & $91.31^{b c}$ & $5.46^{b c}$ & $5.68^{b c}$ & $5.41^{b c}$ & $5.71^{\mathrm{c}}$ & $80.68^{e}$ & $85.18^{\mathrm{e}}$ \\
\hline $\mathbf{T}_{3}$ & $90.24^{b}$ & $92.43^{b}$ & $5.58^{b}$ & $5.88^{\mathrm{b}}$ & $5.73^{b}$ & $5.97^{c}$ & $82.43^{d}$ & $87.29^{d}$ \\
\hline $\mathrm{T}_{4}$ & $91.33^{b}$ & $92.88^{\mathrm{b}}$ & $5.62^{b}$ & $5.86^{b}$ & $5.85^{\mathrm{b}}$ & $6.18^{\mathrm{bc}}$ & $83.55^{c}$ & $90.24^{\mathrm{C}}$ \\
\hline$T_{5}$ & $93.45^{\mathrm{ab}}$ & $94.72^{\mathrm{a}}$ & $5.87^{b}$ & $5.97^{b}$ & $6.34^{\mathrm{ab}}$ & $6.85^{b}$ & $85.15^{b}$ & $92.49^{b}$ \\
\hline$T_{6}$ & $94.96^{\mathrm{a}}$ & $94.81^{a}$ & $6.25^{\mathrm{a}}$ & $6.43^{\mathrm{a}}$ & $6.56^{\mathrm{a}}$ & $6.93^{\mathrm{a}}$ & $90.22^{a}$ & $94.50^{\mathrm{a}}$ \\
\hline $\mathrm{T}_{7}$ & $94.82^{\mathrm{a}}$ & $94.80^{\mathrm{a}}$ & $6.41^{\mathrm{a}}$ & $6.52^{\mathrm{a}}$ & $6.73^{\mathrm{a}}$ & $6.91^{a}$ & $91.64^{\mathrm{a}}$ & $94.87^{a}$ \\
\hline
\end{tabular}

In a column, numbers flowed by the same litter are not significant at $5 \%$ by DMRT.

$\mathrm{T}_{1}$-Control (tap water), $\mathrm{T}_{2-}$ - potassium silicate at $0.1 \%+\mathrm{Ca}$ EDTA at $0.1 \%, \mathrm{~T}_{3^{-}}$potassium silicate at $0.2 \%$ + Ca EDTA at $0.1 \%, \mathrm{~T}_{4}$ - potassium silicate at $0.3 \%+\mathrm{Ca}$ EDTA at $0.1 \%, \mathrm{~T}_{5-}$ potassium silicate at $0.1 \%+\mathrm{Ca}$ EDTA at $0.2 \%, \mathrm{~T}_{6-}$ potassium silicate at $0.2 \%+\mathrm{Ca}$ EDTA at $0.2 \%$ and $\mathrm{T}_{7-}$ potassium silicate at $0.3 \%$ + Ca EDTA at $0.2 \%$. 


\section{Storability studies}

\section{Weight loss percentage}

Data in Table 2 show the effect of preharvest foliar application with potassium silicate and calcium EDTA on weight loss $\%$, firmness, and decay \% of 'Dessert Red' peach fruits during cold storage at $0 \pm 1^{\circ} \mathrm{C}$ with $90-95 \%$ RH for 28 days. Data cleared that weight loss percentages of fruits were increased with the progressing of the cold storage period in both seasons. So, twenty-eight days under cold storage showed the highest weight loss $\%$, whereas the lowest values were recorded after seven days of cold storage in both seasons. Regarding preharvest treatments, data demonstrated that $\mathrm{T}_{6}$ (potassium silicate at $0.2 \%+\mathrm{Ca}$ EDTA at $0.2 \%$ ) and $T_{7}$ (potassium silicate at $0.3 \%$ + Ca EDTA at $0.2 \%$ ) applications showed the lowest losses percent during all cold storage periods $(7,14,21$, and 28 days) in both seasons. On the contrary, the highest values recorded with control fruits in both seasons. Foliar application with $\mathrm{T}_{7}$ treatment showed to be the best one in reducing Peach fruit weight loss $\%$ as compared with control in both seasons. Similar results were cleared by Abd El-Wahab (2015) on Canino apricot and El-Badawy (2012) who reported that the lowest values of both weight loss \% and decay \%, as well as the best results of shelf life were obtained with the using of $1 \%$ chitosan $+4 \% \mathrm{CaCl}_{2}$ as a foliar application on Peach trees.

\section{Fruit firmness (Newton)}

The same Table (2) cleared that, fruit firmness of 'Dessert Red' peach was enhanced by using the above-mentioned pre-harvest applications compared with control in both seasons. Generally, fruit firmness of Peach fruits gradually decreased with the incidence of storage time as for all treatments in both seasons. Foliar application of $\mathrm{T}_{7}$ (potassium silicate at $0.3 \%+\mathrm{Ca}$ EDTA at $0.2 \%$ ) showed the highest fruit firmness values followed by $T_{6}$ (potassium silicate at $0.2 \%+\mathrm{Ca}^{++}$EDTA at $0.2 \%$ ) treatment in most cases compared to other treatments and control in both seasons. On the contrary, fruit firmness of control treatment recorded the minimum values in both seasons. The enhancement effect of spraying treatments on fruit firmness may reflected to the known role of calcium in maintaining cell walls moreover, Silicon application prevents fruit softening by affecting activities of major cell wall degrading enzymes such as cellulase, polygalacturonase, and xylanase (Zhang and Ervin, 2008). Similar results were showed by Nagy (2018) on "Canino" apricots and Gill et al. (2012) they cleared the applications of potassium at different levels enhanced Pear fruit firmness. The declination of fruit firmness during cold storage may be due to the breakdown of insoluble protopectin to soluble pectin, which leads to increase membrane permeability (Matto et al., 1975). This process increases hydrolysis of intercellular pectin, reduces cell turgor pressure, and resulted in an increase in fruit softening (Pollard, 1974).

\section{Fruit decay percentage}

Regarding fruit decay percentage, data in the same Table (2) show that fruit decay $\%$ was increased with increasing the storage time especially from 14 to 28 days of storage, also it could be noticed that the highest fruit decay \% was recorded in control treatment in both seasons. The results showed that foliar spraying with $T_{7}$ (potassium silicate at $0.3 \%+\mathrm{Ca}$ EDTA at $0.2 \%$ ) did not record any fruit decay \% during all storage period ( 28 days) followed by $T_{6}$ 


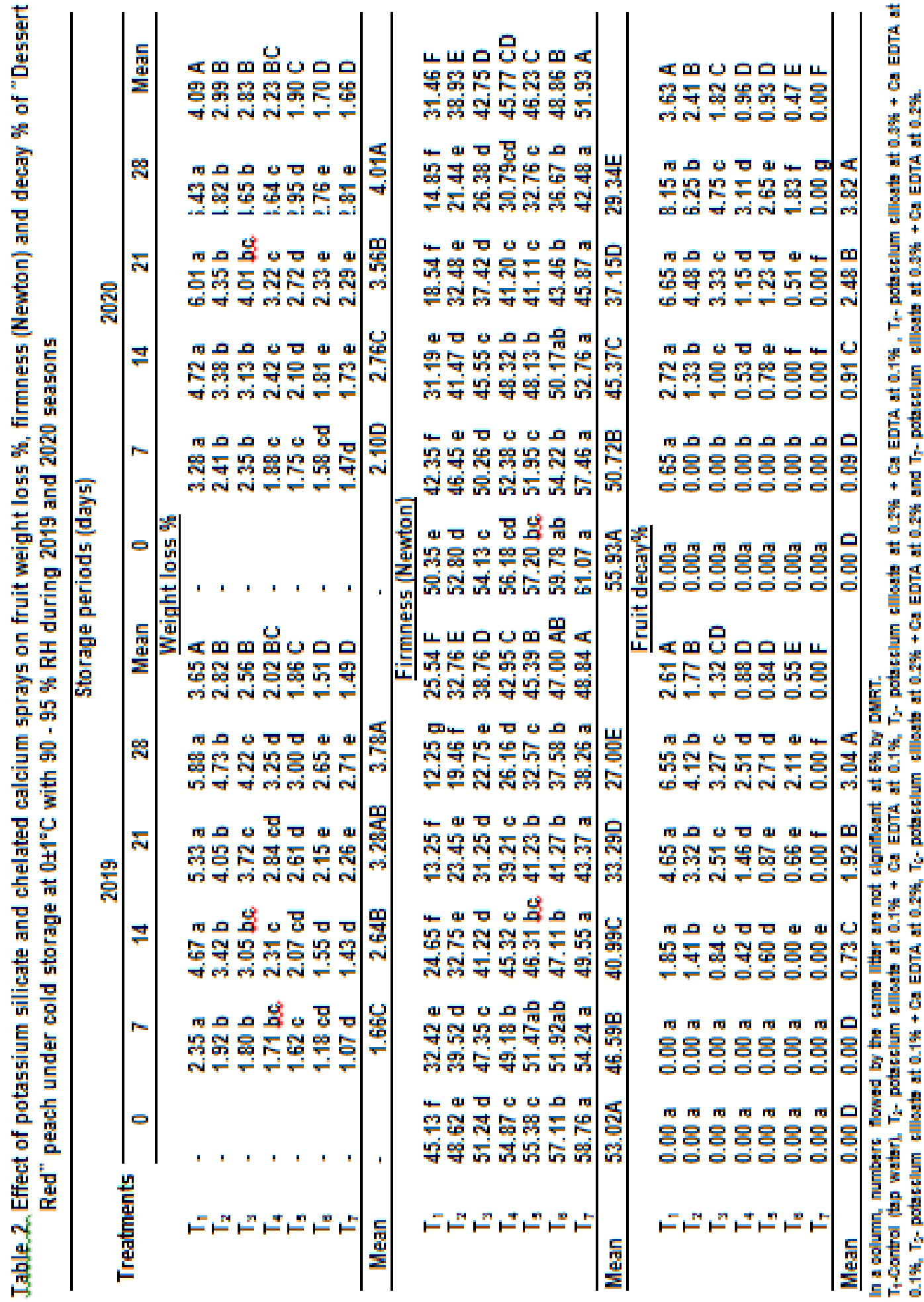


M.H. Abd El-Aziz, et al.,

(potassium silicate at $0.2 \%+\mathrm{Ca}$ EDTA at $0.2 \%$ ) treatment which recorded the lowest values of fruit decay\% as compared to other treatments and control during all cold storage periods. In this respect, control treatment showed the highest decay percentages starting 14 days until the end of cold storage periods in both seasons. Our results are in agreement with those found by Meunier et al. (2011) and Habibi (2015) on grapes. In addition, Meena et al. (2014) reported that $\mathrm{Si}$ applications help to increase the plant absorption water and antioxidant content, which support the defense mechanism system of plants.

Generally, data in Table 2 clear that foliar application of potassium silicate and $\mathrm{Ca}$ EDTA improved physical fruit quality parameters as like fruit weight loss \%, firmness, and decay\% of 'Dessert Red' peach fruits under cold storage at $0 \pm 1^{\circ} \mathrm{C}$ with $90-95 \% \mathrm{RH}$ for 28 days as compared to control in both seasons. The combination between potassium silicate and $\mathrm{Ca}$ EDTA at higher concentration treatment $T_{7}$ (Potassium silicate at $0.3 \%+\mathrm{Ca}$ EDTA at $0.2 \%$ ) showed to be the superior one in enhancing fruit firmness at harvest time. Moreover, it reduced fruit weight loss \%, decay percentages and maintained fruit firmness during cold storage as compared to control. The positive effects of treatments might do to the important role of calcium element on functionality of cell membrane that reduces losses of phospholipids (Abd-rabboh, 2012). Moreover, potassium nutrient affects fruit firmness through several paths that enhanced the pressure potentiality of fruit tissues (Lester et al., 2006). Also, silicon applications enhanced fruit hardness, pressure-resistance, and protein content of some fruits and vegetable crops (Jia et al., 2011). Similar results were obtained by Sharma and
Pratima (2018) and El-Badawy (2012) on Peach.

\section{Fruit chemical parameters: SSC \%}

The results in Table 3 indicated that SSC \% of peach fruits increased as a result of treatments at harvest date compared to control. The highest percent of SSC was recorded in fruits sprayed by $\mathrm{T}_{7}$ (potassium silicate at $0.3 \%$ + Ca EDTA at $0.2 \%$ ) at picking date compared to control in both seasons. Regarding cold storage, SSC \% was gradually increased with the incidence of storage period, and the highest increment values were recorded in control fruits in both seasons. Meanwhile, the lowest value was showed by $T_{7}$ (potassium silicate at $0.3 \%$ + Ca EDTA at $0.2 \%$ ) treatment in the second one, These results mean that the fruit ripening was accelerated with control treatment however, it delayed by using potassium silicate and $\mathrm{Ca}$ EDTA as foliar applications. These results are in agreement with Mazahir et al. (2018) on Sweet Cherries as well as Singh et al. (2017) and Nagy (2018) who reported that calcium applications retarded apricot fruits ripening and maintained SSC \% of the juice. In addition, Abdel Gayed et al. (2017) reported that calcium chloride treatment at both applied concentrations (1and $2 \%$ ) maintained higher SSC $\%$ of 'Early Swelling' peach fruits. In addition, Badran et al. (2015) reported that foliar spray of seaweed extract at $4 \%$ with Silicon at $0.5 \%$ increased fruit diameter, weight, and SSC \% as well as sugars content. Moreover, El Kholy et al. (2018) reported that potassium silicate applications enhanced fruit quality parameters as fruit weight, fruit dimensions fruit pulp, fruit firmness, total soluble solids. The positive effect of treatments on SSC \% may explain according, as the fruit proceed to ripening, as the degradation of polysaccharides to simple sugars 


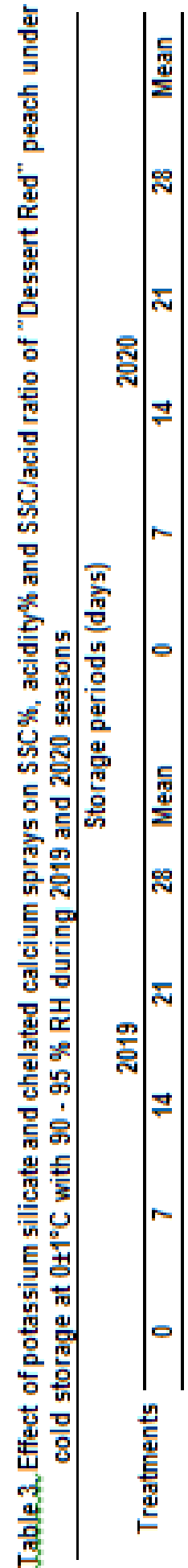

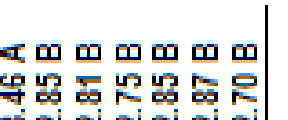

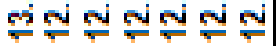

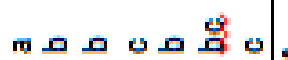

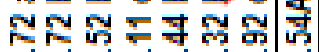

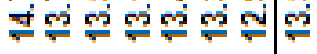
س

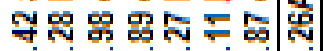

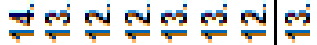

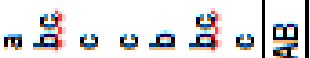

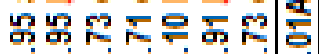

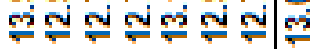
m.

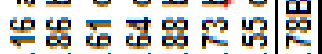

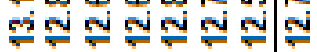
$\mathscr{T}+7 \rightarrow$

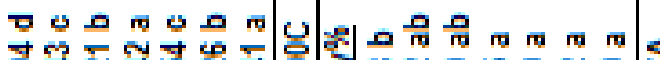

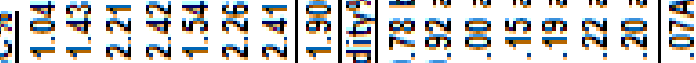

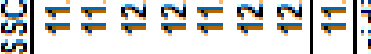

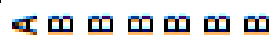

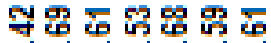
ભำำำำสำ

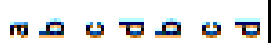

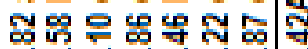

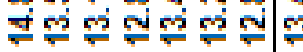
م م م م م م

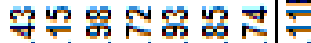
ㅉํำํํำำำ م م م م م م

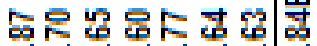

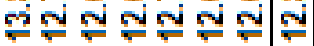
س م م م م م م

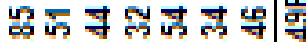
ํำำำำำ

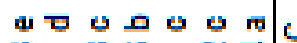

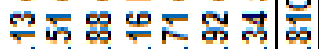

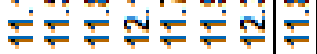
壱

๓

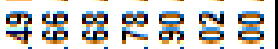

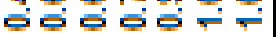
ט

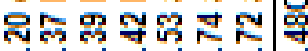

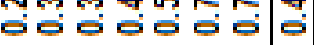
م م م

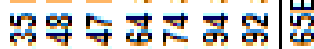
0000000

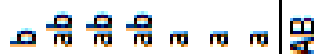

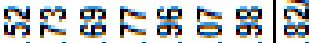

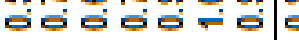

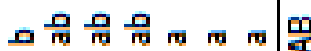

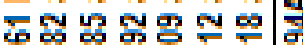

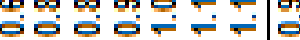
ठ운

๓ $₫ \ll \varangle \ll \varangle$

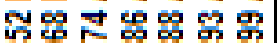
엉ㅇㅇㅇㅇㅇ م

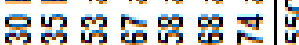
o잉ㅇㅇ잉

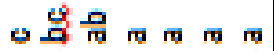

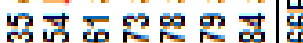

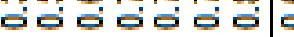

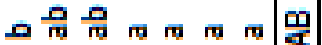

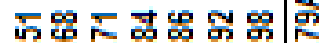

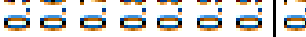
م م م

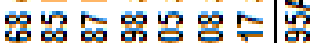
ठ0口ठ ט

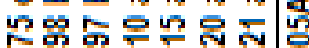

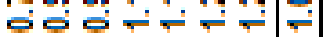

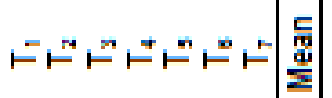

๔m

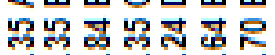

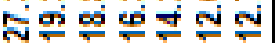

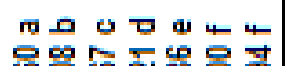

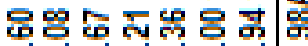

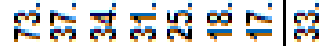
ח م

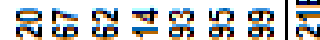
ชลลลำ ซึ่ m造

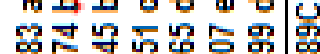

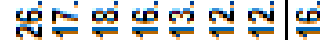
กค

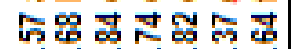

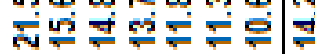

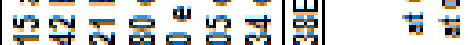

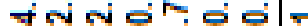
(1)

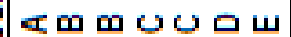

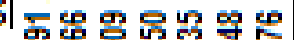

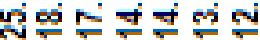
m

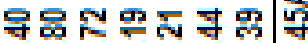

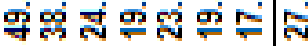
س

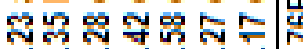

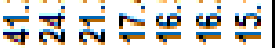
س

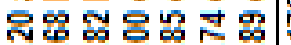

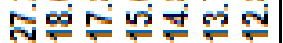

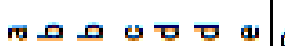

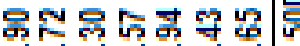

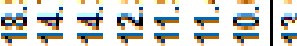
س

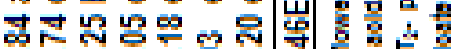

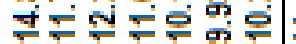

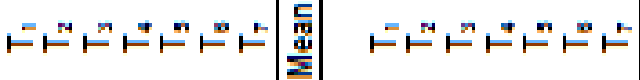


M.H. Abd El-Aziz, et al.,

increased which increase SSC content of fruits, however, Ca plays a major role in slowing down the respiration rate and some metabolic activities of the fruit consequently retards the ripening process (Naik et al., 1993).

\section{Fruit acidity $\%$}

Regarding fruit acidity \%, the results in the same Table (3) revealed that juice acidity values were significantly increased in all treatments as compared to control at the picking date in both seasons. Meanwhile, it was gradually decreased during cold storage, and the rates of decreasing differed among treatments in both seasons. The lowest juice acidity \% were recorded with control fruits treatment during all cold storage periods $(7,14,21$, and 28 days). However, the highest values were recorded with $\mathrm{T}_{7}$ (potassium silicate at $0.3 \%+\mathrm{Ca}$ EDTA at $0.2 \%$ ) and $\mathrm{T}_{6}$ (potassium silicate at $0.2 \%+\mathrm{Ca}$ EDTA at $0.2 \%)$ treatments without significant different between them, this trend was cleared during all the cold storage periods in both seasons. These results clear that foliar applications with potassium silicate and $\mathrm{Ca}$ EDTA retarded the fruit ripening as compared to control during cold storage.

The positive effect of treatments may explained depending on the results of Martin-Diana et al. (2007) and Solhjoo et al. (2017) they cleared the role of $\mathrm{Ca}$ nutrient in retarding fruit ripening process through reduction of both respiration rate and ethylene production. In addition, Conway et al. (2002) reported that the higher application of calcium might be increase the involvement of $\mathrm{Ca}$ in the intra and extracellular processes that causes changes in fruit quality, such as variations in total acid content. Moreover, silicon application had an important role in maintaining fruit quality as showed by El-Khawaga (2014), Abd ElWahab (2015) and El Kholy et al. (2018) they summarized that, potassium silicate applications enhanced all fruit quality parameters in terms of SSC \%, fruit acidity \%and SSC/acid ratio.

\section{SSC/acid ratio}

Concerning SSC/acid ratio in peach fruits, data in Table 3 show that, SSC/acid ratio was significantly increased with the incidence of cold storage periods. However, pre-harvest spray treatments resulted in a significant decrease in SSC/acid ratio in the treated fruits as compared to control at harvest date as well as during cold storage until 28 days. Peach trees received $T_{7}$ (potassium silicate at $0.3 \%+\mathrm{Ca}$ EDTA at $0.2 \%$ ) recorded the lowest SSC/acid ratio in the first season. In the second one, the application of $T_{6}$ (potassium silicate at $0.2 \%+\mathrm{Ca}$ EDTA at $0.2 \%$ ) and $\mathrm{T}_{7}$ (potassium silicate at $0.3 \%+\mathrm{Ca}$ EDTA at $0.2 \%$ ) showed the lowest values in most cases, meanwhile, the highest values were detected in control treatment in both seasons. These results are in harmony with those of Raese and Drake (1993) and Kazemi et al. (2011) they showed the effect of calcium in maintaining fruit quality and retarding losses of acidity \%, slow down respiration rate, delays fruit ripening, thus reducing the acid utilization in respiration. In addition, El Kholy et al. (2018) concluded that foliar spray with $\mathrm{K}_{2} \mathrm{SiO}_{3}$ increased SSC and SSC/acid ratio of Loquat fruits, while total acidity relatively decreased.

\section{Vitamin $\mathbf{C}$ content}

Data in Table 4 show the effect of preharvest treatments on vitamin $C$ content of Peach fruits at harvest date and during cold storage periods. Vitamin C content of fruits significantly increased because of all potassium silicate and Ca EDTA applications as compared with control 
treatment at picking date in both seasons. However, it was gradually decreased under cold storage conditions, especially with the incidence of the storage period in both seasons. Preharvest spraying of $\mathrm{T}_{6}$ (potassium silicate at $0.2 \%+\mathrm{Ca}$ EDTA at $0.2 \%)$ and $\mathrm{T}_{7}$ (potassium silicate at $0.3 \%+\mathrm{Ca}$ EDTA at $0.2 \%)$ maintained the highest values of vitamin C during cold storage up to 28 days as compared to control in both seasons. Similar results were obtained by Davey et al. (2000), Ruoyi et al. (2005) on Prunus and Mazahir et al. (2018) they showed that the application of $\mathrm{Ca}$ nutrient maintained the SSC \% and Vitamin C contents of sweet cherries fruit. Moreover, Johnson (2008) reported that, calcium applications reduced internal tissues break down, reduced intra and extracellular processes that maintaining fruit acids content of peach fruits under cold storage condition. Also, potassium silicate applications at $2 \%$ enhanced different fruit chemical characters such as SSC \%, acidity\%, SSC/acid ratio, and vitamin C in Peach fruits (El Kholy et al. 2018).

\section{Anthocyanin pigments content}

The results in Table 4 cleared the effect of foliar spray with potassium silicate and $\mathrm{Ca}$ EDTA treatments on anthocyanin pigments content of peach fruits. All applications reduced fruit content of anthocyanin at picking date as compared to control meanwhile, the fruits that harvested from peach trees treated by $T_{7}$ (potassium silicate at $0.3 \%$ + Ca EDTA at $0.2 \%$ ) showed the lowest values of anthocyanin content at the picking date in both seasons. Regarding cold storage, anthocyanin pigments content was gradually increased with the incidence of the storage period in both seasons. The same treatment $\left(T_{7}\right)$ showed to be the best treatment for maintaining anthocyanin pigments content of peach fruits during cold storage, since it showed the lowest values up to 28 days under cold storage in both seasons that, mains it was the best one in retarding the fruit ripening during cold storage. These results are in agreement with those of El-Motty et al. (2007), Solhjoo et al. (2017), El Kholy et al. (2018) and Tarabih et al. (2014) They revealed that the shining of fruits (hue angle) value was increased with the application of potassium silicate $\left(\mathrm{K}_{2} \mathrm{SiO}_{3}\right)$ however, retard the accumulation of pigments in fruits during cold storage.

Generally, data in Table 4 clear that, foliar application of $\mathrm{K}_{2} \mathrm{SiO}_{3}$ combined with $\mathrm{Ca}$ EDTA at three times enhanced vitamin C content of peach fruits at picking time, meanwhile retarded the fruit ripening process during cold storage at $0 \pm 1^{\circ} \mathrm{C}$ with $90-95 \% \mathrm{RH}$ for 28 days. The application of potassium silicate at $0.3 \%$ + Ca EDTA at $0.2 \%\left(T_{7}\right)$ produced significantly the highest vitamin $\mathrm{C}$ content in fruits at the same time it was more effective in retarding the accumulation of anthocyanin pigments content under cold storage condition.

\section{CONCLUSION}

Based on the present findings, it could be concluded that pre-harvest foliar application of "Dessert Red" peach trees with potassium silicate at $0.3 \%+\mathrm{Ca}$ EDTA at $0.2 \%$ three times increased yield and improved fruit physical characters as lick fruit weight, length, volume, and chemical quality attributes such as SSC $\%, \mathrm{SSC} / \mathrm{acid}$ ratio and ascorbic acid content at harvesting date. Moreover, it reduced fruit weight loss $\%$, maintained fruit firmness and other chemical quality attributes moreover, retarded the fruit ripening during cold storage at $0 \pm 1^{\circ} \mathrm{C}$ with $90-95 \%$ RH for 28 days. Therefore, "Dessert red" peach trees could be foliar sprayed with the above-mentioned treatment to maintain fruit quality during cold storage. 


\section{REFERENCES}

A.O.A.C., (1990). Association of official analytical chemists. Official Methods of Analysis. $15^{\text {th }}$ Ed. Washington D.C., USA.

Abd El-Motty, E.Z., M.H. El-Sheikh, M.F. Shahin and M.I. Fawzy (2007). Effect of preharvest calcium and boric acid treatments on characteristics and storability of "Canino" apricot fruits. Res. J. Agric. and Biol. Sci., 3(5): 430439.

Abd El-Wahab, S.M. (2015). Apricot postharvest fruit quality, storability and marketing in response to preharvest application. Middle East $J$. Agric., 4 (2): 347-358.

Abdel Gayed, A.A., S.A. Mohamed, A. Shaarawi1, M.A. Elkhishen and N.R.M. Elsherbini (2017). Pre-harvest application of calcium chloride and chitosan on fruit quality and storability of 'Early Swelling' peach during cold storage. Ciência e Agrotecnologia, 41(2): 220-231.

Abd-rabboh, G.A. (2012). Effect of some preharvest treatments on quality of Canino apricot fruits under cold storage conditions. Journal of Horticultural Science \& Ornamental Plants, 4(2): 227- 234.

Ali, I., N.A. Abbasi and I.A. Hafiz (2014). Physiological response and quality attributes of peach fruit cv. Florida king as affected by different treatments of calcium chloride, putrescine and salicylic acid. Pak. J. Agri. Sci., 51(1): 33-39.

Al-Wasfy, M. M. (2014). The synergistic effects of using silicon with some vitamins on growth and fruiting of Flame Seedless grapevines. Stem Cell, 5(1): 8 - 13.

Badran, A.M.F., S.H. Aly, O.A. Khalil and A.Y.M. Ahmed (2015). Improving fruit quality and yield of zaghloul and samany date cultivars by spraying with silicon nutrient. Assiut J. Agric. Sci., 46 (6): 57-66.
Barker, A.V. and D. J. Pilbeam (2015)."Handbook of plant nutrition" CRC press, London, UK.

Brummell, D.A., V. Dal-Cin, S. Lurie, C.H. Crisosto and J.M. Labavitch (2004). Cell wall metabolism during the development of chilling injury in coldstored Peach fruit: association of mealiness with arrested disassembly of cell wall pectins. Journal of Experimental Botany, 55(405): 20412052.

Carlos, H.C. (1994). Stone fruit maturity indices: a descriptive review.

Postharvest News and Information, 5(6): 65-68.

Chardonnet, C.O., C.S. Charron, C.E. Sams and W.S. Conway (2003). Chemical changes in the cortical tissue and cell walls of calciuminfiltrated "Golden Delicious" apples during storage. Postharvest Biology and Technology, 28: 97-111.

Conway, W.S., C.E. Sams and K.D. Hickey (2002). Pre- and postharvest calcium treatment of apple fruit and its effect on quality. Acta Hortic., 594: 413-419.

Crisosto, C. H., R.S. Johnson, T. Dejong and K.R. Day (1997). Orchard factors affecting post-harvest stone fruit quality. J. Hort. Sci., 32: 820-823.

Davey, M.W., M.V. Montagu, D. Inze, M. Sanmarita and J. Fletcher (2000). Plants ascorbic acid, chemistry, function, metabolism, bioavailability and effect of processing. J. Sci. Food Agric., 80, 825-860.

Duncan, D. B. (1955). Multiple ranges and multiple $F$ test. J. Biometrics, 11: 1-42.

El Kholy, M. F., A.A. Mahmoud and S.M.A. Mehaisen (2018). Impact of Potassium Silicate Sprays on Fruiting, Fruit Quality and Fruit Storability of Loquat trees. Middle East Journal of Agriculture Research, 07 (01): 139-153.

El-Alakmy, H.A. (2012). Effect of calcium application and wrapping treatments on fruit quality of Earli Grande peach 
trees (Prunus persica L.). J. App. Sci. Res., 8(7): 3845-3849.

El-Badawy, H. (2012). Effect of chitosan and calcium chloride spraying on fruits quality of "Florida Prince" peach under cold storage. Res. J. Agric., 8: 272-281.

El-Khawaga, A.S. (2014). Impact of vitamins $B$ and $C$, glutamic acid and silicon on fruiting of Superior grapevines. World Rural Observations, 6(4): 57-62.

Gill, P.S., M.Y. Ganaie, W.S. Dhillon and N.P. Singh (2012). Effect of foliar sprays of potassium on fruit size and quality of 'Patharnakh' pear. Indian J. Hort., 69(4): 512-516.

Guntzer, F., C. Keller and J.D. Meunier (2012). Benefits of plant silicon for crops: a review. Agronomy for Sustainable Development, 32: 201-213.

Habibi, G. (2015). Effects of soil- and foliar-applied silicon on the resistance of grapevine plants to freezing stress. Acta Biologica Szegediensis, 59(2): 109-117

Jacobs, M.B. (1951). The chemical analysis of foods and food products: 724-732. D. Van. Nostrand, Inc. Now York, London.

Jia, J.X., D.L. Cai and Z.M. Liu (2011). New progress in silicon-improvement of quality of crops. Proceedings of the $5^{\text {th }}$ International conference on silicon in agriculture September 13-18, 2011 Beijing, China, pp77.

Johnson, R.S. (2008). Nutrient and water requirements of Peach trees. In: Lyne, D.R. and Bassi, D. (eds.). The Peach botany, production and uses. $C A B$ International, 310-311.

Kanai, S., K. Ohkura, J.J. Adu-gyamfi, P.K. Mohapatra, N.T. Nguyen, H. Saneoka and K. Fujita (2007). Depression of sink activity precedes the inhibition of biomass production in tomato plants subjected to potassium deficiency stress. Journal of Experimental Botany, 58: 2917-2928.
Kazemi, M., M. Aran and S. Zamani (2011). Effect of calcium chloride and salicylic acid treatments on quality characteristics of kiwifruit (Actinidia deliciosacv. Hayward) during storage.Am. J. Plant Physiol., 6(3): 183-189.

Kirmani, S.N., G.M. Wani, M.S. Wani, M.Y. Ghani, M. Abid, S. Muzamil, H.Raja and A.R. Malik (2013). Effect of preharvest application of calcium chloride, gibberellic acid and napthelenic acetic acid on storage of plum (Prunus salicina L.) cv. Santa Rosa under ambient storage conditions. Afr. J. Agric. Res., 8(9): 812-818.

Kuchay, M.A., K. Mallikarjuna and M.T. Ali (2018). Effect of foliar sprays of nitrogen and calcium on fruit quality attributes, yield and leaf nutrient content of apple. International journal of pure and appli ed bioscience, 6 (6): 970- 977.

Lester, G.E., J.L. Jifon and D.J. Makus (2006). Supplemental foliar potassium applications with or without a surfactant can enhance netted muskmelon quality, Hort. Science, 41(3): 741-744.

Lurie, S. and C.H. Crisosto (2005). Chilling injury in Peach and Nectarine. Postharvest Biology and Technology, 37: 195-208.

Martin-Diana, A.B., D. Rico, J.M. Frias, J.M. Barat, G.T.M. Henehan and C. Barry-Ryan (2007). Calcium for extending the shelf life of fresh whole and minimally processed fruits and vegetables: a review. Trends Food Sci. Technol., 18: 210-218.

Matto, A.K., T. Murata, E.B. Pantastico, K. Chactin, K. Ogata and C.T. Phan (1975). Chemicalhanges during ripening and senescence. In: Postharvest physiology, handling and utilisation of subtropical fruits and vegetables (Ed. E.B. Pantastico). AVI Publishing Co. Inc. Westport, Connecticut, Pp. 103-127. 
Mazahir, M., Y. Durrani, I. M. Qazi, M. S Hashmi and A. Muhammad (2018). Pre and post-harvest calcium chloride treatments maintain the overall quality of sweet cherries. Fresenius environmental bulletin, 27 (12b): 9696 -9705 .

Mditshwa, A. (2012). The potential of post-harvest potassium silicate dips to mitigate chilling injury on citrus fruit. M.Sc. dissertation University of KwazuluNatal,

Pietermaritzburg, South Africa.

Mditshwa, A., J.P. Bower, I. Bertling, N. Mathaba and S.Z. Tesfay (2013). The potential of postharvest silicon dips to regulate phenolic in peel of citrus pas a method to mitigate chilling injury in lemons. African Journal of Biotechnology.12: 1482-1489.

Meena, V.D., M.L. Dotaniya, V. Coumar, S. Rajendiran, A.S. Kundu and A.S. Rao (2014). A case for silicon fertilization to improve crop yields in tropical soils. Proc. Natl. Acad. Sci., India, Sect. B Biol. Sci., 84(3): 505-518.

Meunier, M., S. Rogiers, G. Gurr and R. Siret (2011). Grapevine vegetative growth and reproductive development in response to silicon supplementation. Proceedings of the $5^{\text {th }}$ International Conference on Silicon in Agriculture September 13-18, pp126.

Mohamed, A.K., H.A. Abdel-Galil and N.H. Galal (2020). Effect of some nutrients and amino acids spraying on yield and fruit quality of Manfalouty pomegranate. SVU-International Journal of Agricultural Science, 2(2): 18-29.

Mosa, W.F., N.A. Abd EL-Megeed, M.A. Aly and L.S. Paszt (2016). Effect of foliar application of potassium and boron on yield and fruit quality of "Florida prince" peach trees. Asian Research Journal of Agriculture, 2(2):1-8.
Nagy, N.M. (2018). Effect of preharvest applications of calcium, antiethylene compounds and their combinations on "Canino" apricot fruit quality and storability. Zagazig J. Agric. Res., 45(5): 1609- 1631.

Naik, D.M., V.G. Mulekar, C.G. Chandel and B.M. Kapse (1993). Effect of prepackaging on physicochemical changes in tomato (Lycopersicon esculentum Mill.) during storage. Indian Food Packer.

Nasar, S., H.M. Korkar and A. Abd-EI Hamid (2013). Evaluation of silicon concentrations and modified atmosphere packaging (MAP) on behavior of pioneer plums under two different storage temperatures. World Journal of Agriculture Science,9: 454465.

Pollard, J.E. (1974). Pectinolytic enzyme activity and changes in water potential components association with internal breakdown in Mclntosh apples. J. Am. Soc. Hort. Sci. 100: 642-649.

Poovaiah, B.W., G.M. Glenn and A.S.N. Reddy (1988). Calcium and fruit softening Physiology and biochemistry. Horticultural Reviews, 10: 107-152.

Preciado-Rangel, P., L. Salas-Perez, M.A. Gallegos-Robles, F.H. Ruiz-Espinoza, A.V. Ayala-Garay, M. Fortis-Hernandez and B. Murillo-Amador (2018). Increasing doses of potassium increases yield and quality of muskmelon fruits under greenhouse. Horticultura Brasileira, 36(2): 184- 188.

Rabino, I., L. Alberto and M. K. Konrad (1977). Photocontrol of anthocyanin synthesis. J. Plant Physiol., 59, 569573.

Raese, J.T. and S.R. Drake (1993). Effect of pre-harvest calcium sprays on Apple and Pear quality. J. Plant Nutr., 16(9): 1807-1918.

Ruoyi, K., Y. Zhifang and L.Z. Zhoxin (2005). Effect of coating and 
intermittent warming on enzymes, soluble pectin substances and ascorbic acid of Prunus persica (cv. Zhonghuashoutao) during refrigerated storage.J. Food Res. Int., 38, 331-336.

Schirra, M., G. D'hallewin, P. Ingleseand and T. La Mantia (1999). Epicuticular changes and storage potential of cactus pear [Opuntia ficusindica Miller (L.)] fruit following gibberellic acid preharvest sprays and postharvest heat treatment. J. Postharvest Biol. Technol., 17: 79-88.

Serrano, M., D. Martinez-Romero, S. Castillo, F. Guillen and D. Valero (2004). Effect of preharvest sprays containing calcium, magnesium and titanium on the quality of Peaches and nectarines at harvest and during postharvest storage. Journal of the Science of Food and Agriculture, 84(11): 1270-1276.

Shahid, M.O., A. Muhmood, M. Ihtisham, M. Rahman, N. Amjad, M. Sajid, K. Riaz and A. Ali (2020). Fruit Yield and quality of 'Florida King' peaches subjected to foliar Calcium chloride sprays at different growth stages. Acta Sci. Pol. Hortorum Cultus, 9(1): 131-139.

Sharma, S.K. and P. Pratima (2018). Effect of pre-harvest gibberellic acid and calcium application on postharvest behaviour of subtropical Peaches. Current Agriculture Research Journal, 6(1): 78 - 84

Shear, C. (1975). Calcium nutrition and quality in fruit crops. $J$. Communications Soil Sci. Plant Analysis, 6: 233-244.

Singh, M., A. Jasrotia, P. Bakshi, K. Kour and R. Kumar (2017). Postharvest calcium treatments and storage intervals influencing physico-chemical attributes of peach cv. Shan-e-Punjab. Journal of Pharmacognosy and Phytochemistry, SP1: 974-979.

Snedecor, G.W. and W.G. Cochran (1990).
Statistical methods. $7^{\text {th }}$ Ed. Iowa State Univ. Press. Ames., lowa, USA, p. 593.

Solhjoo, S., A. Gharaghani and E. Fallahi (2017). Calcium and potassium foliar sprays affect fruit skin color, quality attributes, and mineral nutrient concentrations of 'Red Delicious' apples. International Journal of Fruit Science, 17(4): 358 - 373.

Tarabih, M.E., E.E. El-Eryan and M.A. ElMetwally (2014). Physiological and pathological impacts of potassium silicate on storability of Anna apple. Amer. Jour. of Plant Physiology, 9 (2): 52-67

Toliba, A. O., M.A. Rabie and G. M. ElAraby (2014b). Extending the shelf life of cold stored strawberry by chitosan and carnauba coatings. Zagazig J. Agric. Res., 41(5): 1067-1076.

Valero, D., M. Serrano, M.C. MartínezMadrid and F. Riquelme (1997). Polyamines, Ethylene, and physicochemical changes in lowtemperature-stored Peach (Prunus persica L. CV. aycrest). Journal of agricultural and food chemistry, 45(9): 3406-3410.

Van-Bockhaven, J., D. Vleesschauwer and M. Höfte (2013). Towards establishing broad-spectrum disease resistance in plants: silicon leads the way. J. Exp. Bot., 64 128-129.

Zambrano-Zaragoza, M.L., E. GutiérrezCortez, A. Del-Real, R.M. GonzálezReza, M.J. GalindoPérez and D. Quintanar-Guerrero (2014). Fresh-cut red delicious apples coating using tocopherol/mucilage nanoemulsion: Effect of coating on polyphenol oxidase and pectin methylesterase activities. J Food res. Inter., 62: 974983.

Zhang, X. and E. H. Ervin (2008). Impact of seaweed extract-based cytokinins and zeatinriboside on creeping bentgrass heat tolerance. Crop Sci., 48: $364-370$. 
M.H. Abd El-Aziz, et al.,

تأثير الرش بسيليكات البوتاسيوم وإلكالسيوم المخلبى على محصول وجودة وتخزين ثمار

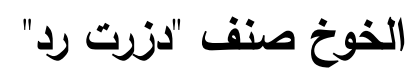

مها حسيب عبد العزيز، محمد على سليمان، حسن أبو الفتوح عناب

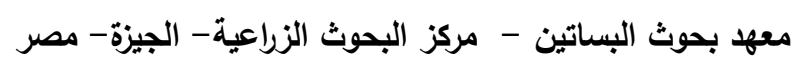

الملخص العربى

أجريت هذه الاراسة على أشجار خوخ صنف دزرت رد عمرها عثر اعوام تتمو فى مزرعة خاصة بمركز الرياض -

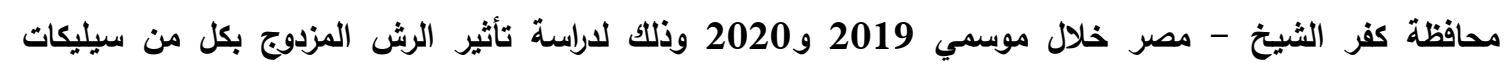

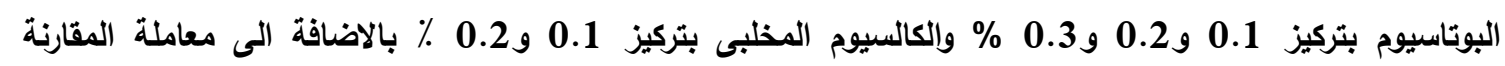

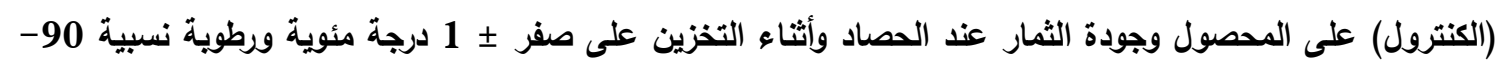
95\% لمدة 28 يومًا. تم رش الأثجار ثثلاث مرات الاولي بعد العقد ثم كل 15 يوم بإحدى المعاملات التالية: الكنترول (ماء الصنبور) - وسيليكات البوتاسيوم بنسبة 0.1 0.1 +

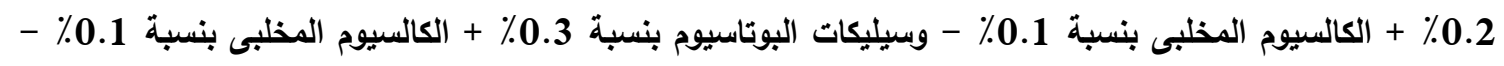

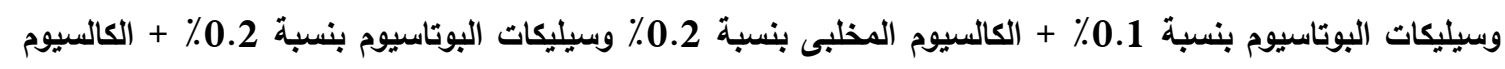

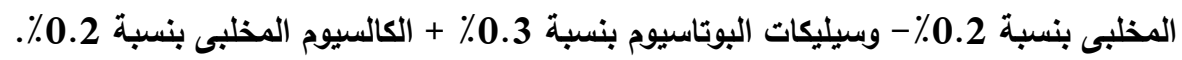

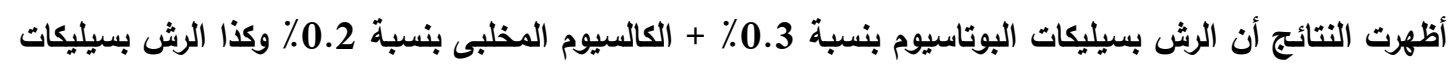

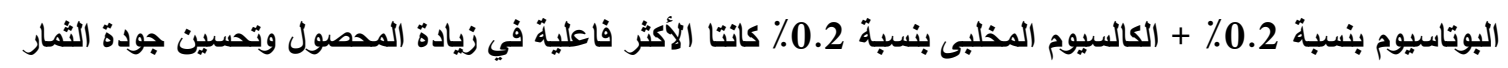

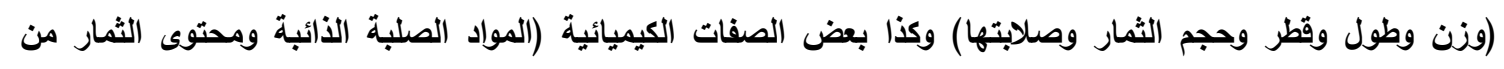

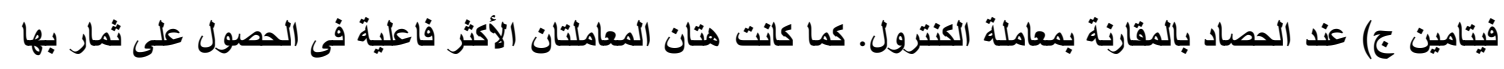

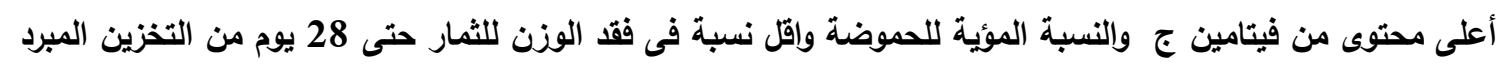

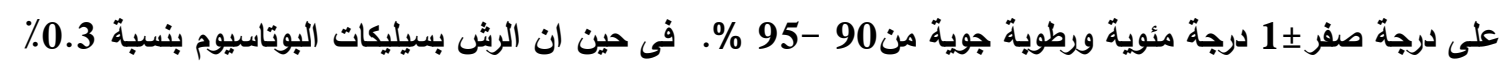

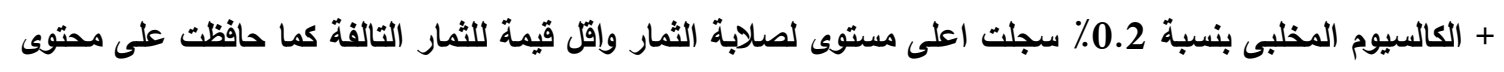

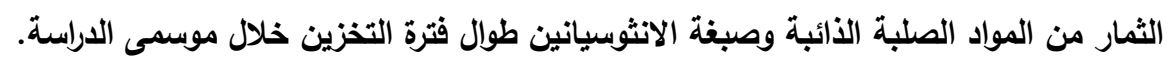

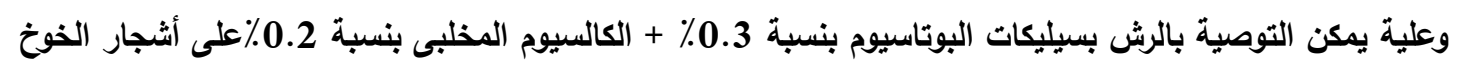
صنف دزرت رد بعد العقد ثم بعد 15 و30 يوم من الرثة الاولى لزيادة المحصول وتحسين صفات الجودة الطبيعية والكيميائية للثمارعند الحصاد والحفاظ عليها أثناء التخزين المبرد.

أسماء السادة المحكمين

أ.د/ محى الدين إبراهيم سلامة كلية الزراعة - كفر الثيخ

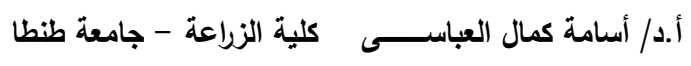

